15. M. Walther. J. Pharm. Chim. 27, 476 (1938); Chem. Abstr, 32, 6237 (1938)

16. C. W. UzRLMEIER. Ph.D. Thesis. Case Institute of Technology, Cleveland, Ohio. 1967.

17. H. C. Brown, Y. OKaMOTO, and G. HaM. J. Am. Chem. Soc. 79, 1906 (1957),

18. K. Ziegler and P. TiemanN. Ber. 55, 3406 (1922).

19. E. Bergmann and A. Welzmann. Trans. Faraday Soc. 32, 1327 (1936).
20. D. Seymour and K. B. WolfstrRn. J. Am. Chem. Soc. 70, 1177 (1948).

21. E. H. FARMer and C. G. Moore. J. Chem. Soc. 131 (1951).

22. E. BOEDTKER and R. KerLor. Compt. Rend. 188 , 1681 (1929).

23. Y. ODAIRA and S. TsutsumI. Technol. Rept. Osaka Univ. 8, No. 307, 199 (1958); Chem. Abstr. 53, 12230 (1959).

\title{
The alkaline decomposition of $o$-phthalaldehyde di-p-toluenesulfonylhydrazone
}

\author{
ClifFord C. LEZNOFF ${ }^{1,2}$ \\ University Chemical Laboratory, Cambridge, England
}

\begin{abstract}
The Bamford-Stevens reaction of $o$-phthalaldehyde di-p-toluenesulfonylhydrazone gives $N-(3,4-$ dihydrophthalazinyl) $p$-tolylsulfone. The product is synthesized by an independent method.
\end{abstract}

The alkaline decomposition of tosylhydrazones $^{3}$ of aldehydes and ketones has been extensively used for the synthesis of olefins (1) and some novel cyclic compounds (2).

The Bamford-Stevens reaction of benzaldehyde tosylhydrazone $(1 a, 1 c)$ under aprotic conditions (3) yields an aryl carbene which dimerizes to trans-stilbene in high yield. Very little is known about the alkaline decomposition of ditosylhydrazones (1a) under aprotic conditions. The ditosylhydrazone of $\sigma$-phthalaldehyde (1) could yield a dicarbenoid (4) species (2) and hence benzocyclobutadiene (3) (5) or some interesting unsaturated macrocyclic compounds.

$o$-Phthalaldehyde ditosylhydrazone (1) was prepared by mixing $o$-phthalaldehyde and $p$ toluenesulfonylliydrazine in a $1: 2$ ratio in ethanol. The use of acetic acid as solvent (6) gave a colored solution. Heating a solution of 1 in dimethyl formamide at $120^{\circ}$, or in diethyl Carbitol at $160^{\circ}$, with either sodium methoxide or sodium hydride gave $N$-(3,4-dihydrophthalazinyl) $p$ tolylsulfone (4) in 5-30\% yield, as the only new substance isolated. ${ }^{4}$ No products derived from benzocyclobutadiene (3) (5) could be detected in the reaction product. Cava and Stein (7) have obtained a similar product by the reaction of

${ }^{1}$ NRCC overseas Postdoctorate Fellow, 1965-1967.

2Present address: Department of Chemistry, York University, Toronto 12 , Ontario.

${ }^{3}$ Tosyl $=$ Ts $=p$-toluenesulfonyl

${ }^{4}$ Ditolyldisulfide and sodium $p$-tolylsulfinate were also formed as side products (see refs. 1c, 9). phthalaldehydic acid tosylhydrazone with excess acetyl chloride in methanol.

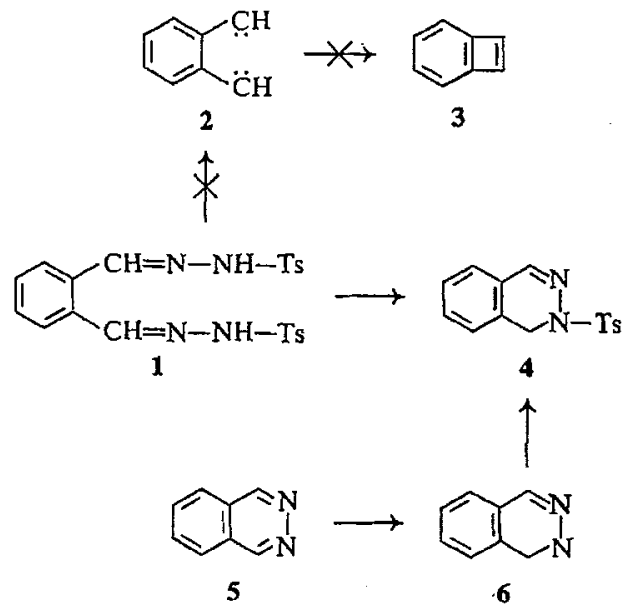

The product 4 was also synthesized by the method of Lemal and Fry (8). Phthalazine (5) was reduced with lithium aluminium hydride to 3,4-dihydrophthalazine (6), and the crude product was treated directly with $p$-toluenesulfonyl chloride in freshly distilled sulfolane and triethylamine.

Dornow and Bartsch $(1 b)$ have reported the formation of sulfones from diazoalkanes and aldehyde tosylhydrazones and hence the conversion of 1 to 4 is not surprising. A likely precursor of 4 may involve a monocarbene resulting from loss of one tosylhydrazone group 
from 1 with subsequent carbene insertion to the $\mathrm{N}-\mathrm{H}$ bond of the remaining tosylhydrazone. The intervention of a protonated diazo compound even under "aprotic" conditions $(8,9)$ cannot be excluded.

\section{Experimental}

Melting points were taken on a Kofler microscope hot-stage and are corrected. Infrared spectra were obtained as $\mathrm{KBr}$ discs on a Unicam SP-200 spectrophotometer. Infrared values $(v)$ are given in $\mathrm{cm}^{-1}$. Nuclear magnetic resonance (n.m.r.) spectra were recorded on a Varian Associates HA-100 spectrometer with tetramethyl silane as an internal standard and deuteriochloroform as solvent. Ultraviolet spectra were obtained in ethanol on a Cary model 14 spectrophotometer. The mass spectra were taken on an A.E.I. MS9 doublefocussing mass spectrometer. Woelm alumina (activity II-III) was used for column chromatography.

o-Phthalaldehyde Ditosylhydrazone ( 1 )

To $2.3 \mathrm{~g}$ of $p$-toluenesulfonylhydrazone in $10 \mathrm{ml}$ of warm absolute ethanol was added $0.8 \mathrm{~g}$ of $o$-phthalaldehyde in $3 \mathrm{ml}$ of absolute ethanol. The solution was heated to refiux for a few minutes and allowed to stand at room temperature for $3 \mathrm{~h}$. The solid was filtered to give $2.7 \mathrm{~g}(96 \%)$ of 1, m.p. $151-152^{\circ}$ (decomp.). The mass spectrum did not give a parent ion (the unusual splitting pattern of tosylhydrazones is well known $(10) ; n . m . r . ~(\tau)$, $7.58 \mathrm{~s}$ (six protons, $\mathrm{Ar}-\mathrm{CH}$ ), $1.8-3.0 \mathrm{~m}$ (complex multiplet which includes aromatic $\mathrm{H}, \mathrm{CH}=\mathrm{N}$, and $\mathrm{NH}$ protons); v 3300; $3100(\mathrm{NH}), 1640(\mathrm{C}=\mathrm{N}), 1595,1560$ (aromatic), 1335, $1165\left(\mathrm{SO}_{2}\right) ; \lambda_{\max } 225 \mathrm{~m} \mu$ (E 28 800), $290(8650)$

Anal. Calcd. for $\mathrm{C}_{22} \mathrm{H}_{22} \mathrm{~N}_{4} \mathrm{O}_{4} \mathrm{~S}_{2}: \mathrm{C}, 56.17 ; \mathrm{H}, 4.71$; $\mathrm{N}, 11.91$. Found: $\mathrm{C}, 56.30 ; \mathrm{H}, 5.32 ; \mathrm{N}, 11.81$.

\section{Alkaline Decomposition of o-Phthalaldehyde}

Ditosylhydrazone (1)

A solution of 1 ( $2.35 \mathrm{~g}, 5$ mmoles) in $20 \mathrm{ml}$ of dimethyl formamide was added to $0.24 \mathrm{~g}$ ( 10 mmoles) of sodiun hydride ${ }^{5}$ in $5 \mathrm{ml}$ of dimethyl formamide at $5^{\circ}$. After being stirred for $1 \mathrm{~h}$, the solution was immersed in an oil bath at $120^{\circ}$. After $5 \mathrm{~min}$ at this temperature, nitrogen evolution had ceased. The reaction mixture was filtered, the filtrate was extracted into ether, and washed six times with water. The semi-crystalline residue was chromatographed to give $300 \mathrm{mg} \mathrm{(21 \% )} \mathrm{of} \mathrm{a} \mathrm{crystalline} \mathrm{compound}$ m.p. $169-171^{\circ}$ in the $1: 1$ pentane : ether fractions. Recrystallization from ether-pentane gave product 4 , m.p. $171-173^{\circ}$. The mass spectrum gave a parent ion at $m / e 286$, as well as large peaks at $m / e 285,155$, and 130 , which would be consistent with structure 4 ; n.m.r. ( $\tau$ ) $7.56 \mathrm{~s}(\mathrm{Ar}-\mathrm{CH}), 5.54 \mathrm{~s}\left(\mathrm{CH}_{2}-\mathrm{N}\right), 2.0-3.0$ (eight aromatic protons); $v 3450$ br (NH), 1600 (aromatic), $1370,1180 \mathrm{~s}\left(\mathrm{SO}_{2}\right) ; \lambda_{\max } 222 \mathrm{m \mu}(\varepsilon 22100), 290$ (9030).

Anal. Calcd. for $\mathrm{C}_{15} \mathrm{H}_{14} \mathrm{~N}_{2} \mathrm{O}_{2} \mathrm{~S}: \mathrm{C}, 62.93 ; \mathrm{H}, 4.93$; N, 9.79. Found: C, $62.80 ; \mathrm{H}, 5.32 ; \mathrm{N}, 9.97$.

In a similar reaction in which only one equivalent of sodium hydride was used, the product $\mathbf{4}$ was obtained in $14 \%$ yield. When the reaction was carried out in dry diethyl Carbitol at $160^{\circ}$ with two equivalents of sodium

${ }^{5}$ The sodium hydride was freed from mineral oil by washing with dry pentane. methoxide, only a $6 \%$ yield of 4 was obtained. All the reactions were carefully examined by thin-layer chromatography for hydrocarbon components, but none could be detected.

\section{Alternative Synthesis of $N-(3,4-D i h y d r o p h t h a l a z i n y l)_{p}$ - \\ tolylsulfone (4)}

To a stirred slurry of lithium aluminium hydride $(0.38 \mathrm{~g}, 10$ mmoles) in $10 \mathrm{ml}$ of ether under nitrogen, was added dropwise a solution of $1.3 \mathrm{~g}$ (10 mmoles) of phthalazine (5) in $20 \mathrm{ml}$ of tetrahydrofuran. The mixture was then refluxed for $8 \mathrm{~h}$. Water ( $1 \mathrm{mll}$ ) was added and the mixture was filtered through a filter cel-magnesium sulfate pad. The solvent was removed under reduced pressure. Thin-layer chromatography and elution of the product with ether showed mainly one spot $\left(R_{f}, 0.8\right.$; phthalazine $R_{f}, 0.05$ ). One half of the product (6) was dissolved in $17.5 \mathrm{ml}$ of freshly distilled sulfolane, and $0.8 \mathrm{ml}$ ( 5 mmoles) of triethylamine and $950 \mathrm{mg}$ ( 5 mmoles) of $p$-toluenesulfonylchloride were added. The solution was heated at $140-150^{\circ}$ for $1.5 \mathrm{~h}$, cooled, and then extracted with ether. The resulting oil on chromatography in the 1:1 pentane-ether fractions gave $100 \mathrm{mg}$ of 4 , m.p. $172-174^{\circ}$, undepressed upon admixture with the product obtained above; mass spectrum was identical to that obtained previously.

Anal. Calcd. for $\mathrm{C}_{15} \mathrm{H}_{14} \mathrm{~N}_{2} \mathrm{O}_{2} \mathrm{~S}: \mathrm{C}, 62.93 ; \mathrm{H}, 4.93$; $\mathrm{N}, 9.79$. Found: $\mathrm{C}, 62.70 ; \mathrm{H}, 4.93 ; \mathrm{N}, 10.20$.

\section{Acknowledgment}

The author wishes to express his thanks to Professor F. Sondheimer for advice and interest in this work.

1. (a) W. R. BAmford and T. S. Stevens. J. Chem. Soc. 4735 (1952). (b) A. DorNow and W. BARTSCH Ann. 602, 23 (1957). (c) H. NOZAKI, R. NOYORI, and K. Sisido. Tetrahedron, 20, 1125 (1964).

2. G. L. Closs, L. E. Closs, and W. A. BöLL, J. Am. Chem. Soc. 85, 3796 (1963). G. L. Closs and R. B. LARRABEe. Tetrahedron Letters, 287 (1965). M. SCHWARZ, A. Besold, and E. R. NeLson. J. Org. Chem. 30, 2425 (1965). A. C. UdDing, J. STrÁting, H. Wynberg, and J. L. M. A. SChlatmanN. Chem. Commun. 657 (1966).

3. J. W. POWELL and $M$. C. Whrting. Tetrahedron, 7,305 (1959). L. FRIEDMAN and H. SHECATER. J. Am. Chem. Soc. 81, 5512 (1959). L. Friedman and H. SHEChTER, J. Am. Chem. Soc. 82, 1002 (1960)

4. W. KIRMSE. In Carbene chemistry. Edited by A.T. Bloomquist. Academic Press, Inc., New York. 1964. Chap. 10.

5. M. P. CAva and D. R. Napter. J. Am. Chem. Soc. 79, 1701 (1957). M. Avram, D. DINU, and C. D. NentTzescu. Chem. Ind. London, 257 (1959). M.P. CAVA and M. J. MrTCHell. In Cyclobutadiene and related compounds. Edifed by A. T. Bloomquist. Academic Press, Inc., New York. 1967. Chap. 6.

6. D. G. FARNuM. J. Örg. Chem. 28, 870 (1963).

7. M. P. CAVA and R. P. Stein. J. Org. Chem, 31, 1866 (1966)

8. D. M. Lemal and A. J. FrY. J. Org. Chem. 29, 1673 (1964)

9. J. W. WILT, C. A. Schneider, H. F. DABek, JR., J. F KRAEMER, and W. J. WAGNER. J. Org. Chem. 31, 1543 (1966)

10. A. Bhati, R. A. W. Johnstone, and B. J. MLLLARD. J. Chem. Soc. 358 (1966) 